\title{
BUDAYA AKADEMIK DALAM SISTEM PENDIDIKAN DAYAH SALAFIYAH DI ACEH
}

\author{
Silahuddin \\ Fakultas Tarbiyah dan Keguruan UIN Ar-Raniry \\ J1. Syeikh Abdur Rauf Kopelma Darussalam, Banda Aceh, Aceh, 23111 \\ e-mail: sila_huddin@yahoo.com
}

\begin{abstract}
Abstrak: Artikel ini mengkaji budaya akademik dalam sistem pendidikan dayah Salafiyah di Aceh. Secara historis, dayah dikenal telah melahirkan banyak ulama dari berbagai disiplin ilmu, sehingga akan menarik untuk mengkaji perkembangan budaya akademik pada sistem pendidikan dayah yang melahirkannya. Artikel ini menggunakan pendekatan penelitian kualitatif, dan menemukan bahwa budaya akademik di dayah Salafiyah masih belum berkembang. Kondisi ini lebih disebabkan oleh empat faktor, yakni budaya akademik di dayah telah berkembang secara turun temurun, masih menggunakan kurikulum dan metodologi pengajaran yang masih tradisional, serta organisasinya belum dikelola dengan manajemen yang sistematis. Keempatnya berpengaruh pada budaya akademik dalam sistem pendidikan dayah yang meliputi budaya belajar, memberi pendapat, pengembangan keilmuan, dan berorganisasi.
\end{abstract}

\begin{abstract}
Academic Culture of Dayah Salafiyah Education System in Aceh. As a center of education, propagation, and religious development, Dayah (traditional Islamic boarding school) has produced a large number of ulama from various fields of disciplines. This article attempts to study academic culture of Dayah Salafiyah education system in Aceh. This articles utilizes qualitative approach, and found that academic culture of Dayah Salafiyah has not yet developed. It is argued that there are at least four aspects that underpins the condition, namely, academic culture, the use of traditional curriculum, methology as well as organization. In reality, however, the academic culture of Dayah has not shown an open and inclusive culture. As such, the existence of Dayah has been put under a big question mark. Although the number of Dayah has been significantly increasing in Aceh Besar, its teaching and learning quality has been declining, and its roles in government and community system have also been weakening.
\end{abstract}

Kata Kunci: budaya akademik, dayah, Salafiyah, sistem pendidikan 


\section{Pendahuluan}

Pendidikan merupakan sebuah proses untuk mengangkat harkat, martabat dan kesiapan manusia dalam menghadapi masa depan yang penuh dengan tantangan, serta mengamalkan nilai-nilai yang terkandung dalam pendidikan. ${ }^{1}$ Pendidikan sebagai usaha untuk mentransfer nilai-nilai budaya Islam kepada generasi muda. Pendidikan juga merupakan proses transformasi budaya. Salah satu tempat untuk mentransformasi budaya dan keilmuan adalah lembaga pendidikan, baik lembaga pendidikan formal maupun pendidikan non formal. Dayah merupakan salah satu lembaga pendidikan dan tempat pewarisan budaya dari satu generasi ke generasi berikutnya.

Dayah merupakan bagian yang tidak terpisahkan dari tradisi masyarakat Aceh. Keberadaan dayah memiliki sejarah yang panjang, mengakar kuat dalam masyarakat, baik dalam pola kehidupan sosial, budaya dan keagamaan. Dayah juga merupakan lembaga pendidikan tradisional Islam yang mengajari, memahami, menghayati dan mengamalkan ajaran agama dalam kehidupan sehari-hari dengan menekankan kepada pentingnya moral agama sebagai pedoman hidup dalam masyarakat. ${ }^{2}$ Dayah adalah lembaga pendidikan pertama dan tertua bagi umat Islam di Aceh serta tempat mempelajari kitab-kitab klasik. ${ }^{3}$

Dayah juga merupakan salah satu tempat untuk menuntut ilmu dan mengembangkan pengetahuan serta budaya. Pendidikan merupakan salah satu faktor yang menentukan dan berpengaruh terhadap perubahan sosial. Melalui pendidikan diharapkan bisa dilahirkan generasi penerus yang mempunyai karakter untuk mampu menerima tongkat estafet kepemimpinan bangsa. Tahar Yusuf mengemukakan bahwa pendidikan merupakan usaha sadar generasi tua untuk mengalihkan pengalaman, pengetahuan, kecakapan, formalitas pendidikan yang ditekankan dalam pendidikan Islam, dan keterampilan kepada generasinya supaya kelak menjadi manusia bertakwa kepada Allah SWT. dan bertawakal kepadaNya. ${ }^{4}$ Pendidikan Islam dalam era perkembangan ilmu dan teknologi dewasa ini, semakin dipertanyakan relevansinya, terutama jika dikaitkan dengan kontribusinya bagi pembentukan karakter, budaya modern yang dipengaruhi oleh perkembangan ilmu dan teknologi. Dalam konteks ini, pendidikan mengalami degradasi fungsional karena pendidikan semakin berorientasi materialistik, ${ }^{5}$ sehingga pendidikan di dayah menjadi salah satu pilihan bagi orang tua dan masyarakat.

${ }^{1}$ Abdul Hadi, "Konsep Pendidikan al-Fârâbî dan Ibn Sînâ," dalam Jurnal Ilmiah Sintesa, Vol. 9. No. 2, Januari 2010, h. 14.

${ }^{2}$ Mastuhu, Dinamika Sistem Pendidikan Pesantren (Jakarta: INIS, 1994), h. 6.

${ }^{3}$ Kitâb-kitâb klasik yang diajarkan di Dayah dapat digolongkan ke dalam Nahu dan Saraf, Fikih, Usul Fikih, Hadis, Tafsir, Tauhid, Akhlak/Tasawuf, Balâghah dan Târîkh Islam, lihat Zamakhsyari Dholfier, Tradisi Pesantren: Studi tentang Pandangan Hidup Kyai (Jakarta: LP3ES, 1982), h. 50.

${ }^{4}$ Tahar Yusuf, "Model Pendidikan Islam Era Modernisasi: Suatu Kajian Teoritis dan Historis," (Pidato Pengukuhan Guru Besar IPI pada IAIN Imam Bonjol Padang, 1994), h. 19-23.

${ }^{5}$ M. Rusli Karim, Pendidikan Islam di Indonesia (Yogyakarta: Tiara Wacana Yogya, 1991), h. 127. 
Sebagaimana yang ditulis oleh Zamakhsyari, pesantren/dayah sebagai sebuah lembaga pendidikan yang telah melahirkan banyak ilmuwan dalam berbagai macam disiplin ilmu agama sepeti pengetahuan fikih, tauhid, bahasa Arab, penceramah dan khatib, kepandaian berpidato dan berdebat dan menanamkan tanggung jawab untuk melestarikan dan menyebarkan pengetahuan mereka tentang agama Islam kepada orang lain, serta mencurahkan waktu dan tenaga untuk belajar sepanjang hidup. ${ }^{6}$

Sebagai lembaga pendidikan, dayah lahir dari bantuan masyarakat dan telah membuktikan kiprahnya sejak pra kemerdekaan sampai sekarang ini, dan telah banyak melahirkan generasi yang mandiri dalam masyarakat. Dayah telah banyak melahirkan tokoh dan cendikiawan Islam, di antara mereka ada yang menjadi ulama dan pemimpin. Pada zaman penjajahan, dayah mampu melahirkan tokoh-tokoh perjuangan yang mengorbankan jiwa dan raganya demi mempertahankan agama dan membela tanah air.

Berkembangnya dayah pada masa dahulu tidak terlepas dari berkembangnya budaya akademik. Untuk mengembangkan mutu pendidikan diperlukan adanya pengembangan budaya akademik dengan membangun nilai-nilai dan norma-norma yang menampilkan suasana akademik, yaitu suasana yang sesuai nilai-nilai dan kaidah-kaidah ilmiah dalam upaya memperoleh dan mengembangkan pengetahuan. Suasana tersebut perlukan, dipelihara, dan dibina di lembaga pendidikan. ${ }^{7}$

M. Hasbi Amiruddin mengatakan bahwa ulama-ulama alumni dayah pada masa ini disadari atau tidak telah termarginalisasi. Sebagian besar di antara mereka masih memilih tinggal di dayah dan sebagian lainnya terjun ke masyarakat untuk mengadakan pengajian, pengabdian sosial, melaksanakan fardu kifayah, dan kegiatan lainnya. Peranan ulama sebagai pemikir dan penulis seperti pada masa lalu tidak muncul lagi pada alumni dayah sekarang. Sebagian fungsi ulama seperti imam salat telah digantikan oleh alumni-alumni madrasah yang menyediakan pelajaran hapal al-Qur'an. Untuk kegiatan agama lainnya seperti pembacaan doa di event-event tertentu sudah sering digantikan oleh tamatan madrasah atau universitas agama yang fasih berbahasa Arab.

Di samping itu juga banyak ditemukan anak-anak ulama dayah yang banyak beralih ke lembaga pendidikan di luar dayah, mulai dari sekolah menengah sampai perguruan tinggi. ${ }^{8}$ Pernyataan yang sama juga disampaikan oleh In'am Sulaiman. Menurutnya perkembangan pesantren pada masa kini statis dan hampir bisa dikatakan tidak berkembang. Pesantren hanya mempertahankan tradisinya yang didapati secara turun temurun atau

${ }^{6}$ Dhofier, Tradisi Pesantren, h. 22.

${ }^{7}$ Lihat Asih Menanti, et al., Membangun Budaya Akademik di Universitas Negeri Medan (Medan: Unimed, 2012).

${ }^{8}$ Lihat M. Hasbi Amiruddin, Dayah 2050: Menatap Masa Depan Dayah di Era Transformasi Ilmu dan Gerakan Keagamaan (Yogyakarta: Hexagon, 2013). 
orientasi ke belakang atau salaf-oriented, tidak berkembangnya budaya menulis dan membaca, dan manajemen pengelolaan tidak sistematis. ${ }^{9}$

Metode-metode pembelajaran yang digunakan di dayah salafiyah cenderung menimbulkan kejenuhan dan kebosanan, pasif dan santri yang tidak aktif dalam mengembangkan materi pembelajaran. Kitab kuning yang dijadikan acuan dalam belajar lebih menekankan pada aspek penghapalan dan pendalaman, namun hanya sedikit yang mengarah pada pengembangan wawasan, ide, konsep, dan teori keilmuan, dan di dayah juga berkembang doktrin yang cenderung membelenggu santri dalam upaya mengembangkan keilmuan dan kemampuan berpikir serta berinovatif.

Padahal dalam sejarah perjuangan Aceh, lembaga pendidikan dayah pernah mencapai kemajuan. Lembaga pendidikan ini telah melahirkan sejumlah ilmuwan dalam berbagai cabang ilmu, yaitu ahli ilmu pertanian, ahli kelautan, ahli ilmu falak, ahli kemiliteran termasuk mampu memproduk panglima perang yang tangguh, tehnokrat kerajaan bahkan rajaraja dalam kerajaan Islam Aceh. ${ }^{10}$ Dayah sebagai sebuah institusi pendidikan Islam tradisional yang ada di tengah-tengah masyarakat Aceh yang mendidik dan membekali masyarakat dengan pendidikan agama. Institusi ini juga yang telah menyatukan umat dan menjadi benteng pertahanan dari pengaruh globalisasi dan dekadensi moral.

Pada zaman sekarang eksistensi dayah sudah mulai dipertanyakan, secara kuantitatif jumlah dayah di Aceh Besar mengalami peningkatan yang signifikan, tetapi secara kualitas masih dipertanyakan. Jarang didapati karya tulis ilmiah yang dihasilkan oleh alumni dayah yang digunakan sebagai rujukan baik pada level daerah, nasional maupun internasional.

Berdasarkan latar belakang masalah di atas, yang menjadi masalah dalam penelitian ini adalah jika dilihat dari aspek sejarah dan perannya, dayah telah melahirkan banyak ulama dan cendikiawan dalam berbagai macam disiplin ilmu. Sejak kedatangan Islam ke Aceh, dayah telah memainkan peranannya yang penting dalam berbagai aspek kehidupan masyarakat. Namun di era globalisasi pendidikan di dayah mengalami kemunduran, mulai tergusur oleh pendidikan umum, berkembang doktrin yang cenderung membelenggu santri dalam pemikirannya, metodologi yang digunakan cenderung menimbulkan kejenuhan dan kebosanan. Semestinya dayah mempertahankan keunggulannya seperti dayah pada masa dahulu. Fokus kajian ini adalah perkembangan budaya akademik pada sistem pendidikan dayah di Aceh Besar, dan format pengembangan budaya akademik budaya akademik dalam sistem pendidikan dayah salafiyah di Aceh Besar pada masa yang akan datang.

${ }^{9}$ Lihat In'am Sulaiman, Masa Depan Pesantren: Eksistensi Pesantren di Tengah Gelombang Modernisasi (Malang: Madani, 2010).

${ }^{10}$ M. Hasbi Amiruddin, Menatap Masa Depan Dayah di Aceh (Banda Aceh: Yayasan Pena, 2008), h. 15. 


\section{Metode Penelitian}

Mengacu dari permasalahan yang diajukan, penelitian ini memfokuskan pada metode penelitian kualitatif yang bertujuan untuk mendapatkan gambaran yang mendalam tentang budaya akademik dan implementasinya dalam sistem pendidikan dayah salafiyah. Subjek dari penelitian ini adalah dayah salafiyah yang ada di kabupaten Aceh Besar. Populasinya dalam penelitian ini adalah seluruh dayah Salafiyah di Aceh Besar, sedangkan yang menjadi sampel Dayah Ruhul Islam Desa Lambeugak Kecamatan Kuta Cot Glie Kabupaten Aceh Besar, Dayah Ruhul Falah Desa Leupung Riwat Kecamatan Kuta Malaka Kabupaten Aceh Besar, dan Dayah Darul Magfirah Desa Umong Siribee Kecamatan Lhoong Kabupaten Aceh Besar.

Populasi dalam penelitian ini adalah seluruh pimpinan dayah, tenaga pengajar dan santri, sedangkan yang menjadi sampel adalah pimpinan dayah, tenaga pengajar dan santri pada tiga dayah tersebut. Pemilihan sampel dilakukan secara stratified random sampling karena mereka dianggap representatif untuk tujuan penelitian ini. Peneliti melakukan observasi ke dayah-dayah yang telah ditentukan dan serta melakukan wawancara dengan 3 pimpinan dayah, 3 tenaga pengajar yang mengajar pada masing-masing dayah tersebut dan 3 santri yang menetap atau yang tidak menetap di dayah tersebut. Teknik pengumpulan data yang dipilih adalah dengan menggunakan alat/instrumen observasi mendalam (in depth observation) serta evaluasi pengembangan budaya akademik di dayah. Di samping itu juga telah diwawancarai satu orang dari kepala Badan Dayah Aceh Besar, satu kepala Kementerian Agama Kabupaten Aceh Besar dan satu Ketua Majelis Pendidikan Daerah Kabupaten Aceh Besar.

\section{Hasil dan Pembahasan}

\section{Budaya Akademik dalam Pendidikan}

Budaya atau culture adalah segala usaha dan aktivitas manusia dalam mengelola dan merubah alam. ${ }^{11}$ Budaya merupakan suatu cara hidup yang berkembang dan dimiliki bersama oleh sekelompok orang dan diwariskan dari satu generasi ke generasi berikutnya. Budaya terbentuk dari beberapa unsur seperti unsur agama, politik, adat istiadat, bahasa, dan karya seni manusia. Budaya dapat dilihat dari dua sisi yaitu dari sisi spirit dan nilainilai kualitas kehidupan, dan dari sisi manisfestasi atau tampilan budaya. Budaya dapat ditinjau dari tiga aspek yaitu budaya sebagai tata kelakuan manusia, budaya sebagai kelakuan manusia, dan budaya sebagai hasil kelakuan manusia.

Budaya sering juga disebut dengan tradisi. Tradisi diartikan sebagai ide umum, sikap dan kebiasaan dari masyarakat yang tampak dari perilaku sehari-hari yang menjadi kebiasaan dari kelompok dalam masyarakat tersebut. ${ }^{12}$ Sementara itu, budaya juga bisa dikelompokkan

\footnotetext{
${ }^{11}$ Koentjaraningrat, Pengantar Antropologi (Jakarta: Aksara, 1969), h. 76-77.

${ }^{12}$ Soekarto Indrafchrudi, Bagaimana Mengakrabkan Sekolah dengan Orang Tua Murid dan Masyarakat (Malang: IKIP Malang, 1994), h. 20.
} 
berdasarkan tinjauan dari aspek wujudnya, seperti pikiran, pengetahuan, nilai, keyakinan, norma dan sikap, aspek aktivitas seperti pola komunikasi, tari-tarian, upacara adat dan aspek material hasil benda seperti, seni, dan peralatan. ${ }^{13}$ Salah satu unsur budaya yang terpenting adalah adanya kerangka aspirasi, dalam artian ada nilai budaya yang merupakan konsepsi abstrak yang hidup di dalam alam pikiran. ${ }^{14}$

Budaya merupakan faktor yang penting dalam membentuk pola hidup manusia untuk menjadi lebih optimis, berani, berperilaku kooperatif, memiliki kecakapan personal dan akademik. Untuk mencapai keunggulan akademik sebuah lembaga pendidikan perlu memperhatikan perkembangan nilai-nilai (values), keyakinan (beliefs), dan budaya. ${ }^{15}$

Menurut Deddy Mulyana dan Jalaluddin Rahmat, budaya adalah suatu cara hidup yang berkembang dan dimiliki bersama oleh suatu kelompok orang dan diwariskan dari satu generasi ke generasi berikutnya. Budaya bisa dikatakan sebagai suatu pola hidup yang menyeluruh, bersifat komplek, abstrak dan luas, aspek budaya juga turut menentukan perilaku komunikatif. ${ }^{16}$ Ada beberapa cara terbentuknya budaya. Pertama, adanya hubungan antar perilaku atau yang disebut dengan komunikasi budaya. Interaksi dapat terjadi akibat adanya kepentingan dan kebutuhan saling berhubungan satu sama lainnya. Dalam lembaga pendidikan seperti pendidik dan anak didik. Pendidik membutuhkan kompensasi tertentu dari anak didiknya, sedangkan anak didik membutuhkan ilmu pengetahuan dari pendidik. Kedua, konflik kepentingan atau benturan antar budaya, pertikaian atau perselisihan dapat disebabkan oleh kepentingan yang berbeda. Apabila salah satu pihak memaksakan kehendaknya agar kepentingannya lebih diperhatikan dari pada yang lain, akan muncul kecemburuan sosial yang berakibat pada pertikaian. Jika kedua belah pihak merasakan bahwa pertikaian akan merugikan, biasanya dilakukan kompromisasi antar kepentingan. Melalui perdamaian dan musyawarah mufakat, keduanya dapat bersatu, sehingga dari perbedaan kepentingan yang diintegrasikan akan tercipta potensi budaya yang lebih kuat karena keduanya dapat tersalurkan dengan baik. Ketiga, penggalian nilai-nilai intrinsik dalam pluralisme kebudayaan, setiap potensi yang terdapat dalam diri manusia, sebagai individu maupun sebagai masyarakat memiliki nilai-nilai yang berharga untuk membentuk simbol-simbol kebudayaan, sehingga suatu organisasi mempunyai karakteristik tersendiri yang membedakan dengan organisasi lainnya. ${ }^{17}$

\footnotetext{
${ }^{13}$ Koentjaraningrat, Rintangan-rintangan Mental dalam Pembangunan Ekonomi di Indonesia (Jakarta: Lembaga Riset Kebudayaan Nasional Seni, 1969), h. 17.

${ }^{14}$ Fernandez, S.O, Citra Manusia Budaya Timur dan Barat (NTT: Nusa Indah, 1990), h. 28.

${ }^{15}$ Dalam Kamus Besar Bahasa Indonesia, budaya (cultural) diartikan sebagai pikiran, adat istiadat, sesuatu yang sudah berkembang atau sesuatu yang menjadi kebiasaan yang sukar diubah, lihat Departemen Pendidikan dan Kebudayaan, Kamus Besar Bahasa Indonesia (Jakarta: Balai Pustaka, 1991), h.149.

${ }^{16}$ Deddy Mulyana dan Jalaluddin Rahmat, Komunikasi antar Budaya: Panduan Berkomunikasi dengan Orang-orang Berbeda Budaya (Bandung: Remaja Rosdakarya, 2006), h. 25.

${ }^{17}$ Hikmat, Manajemen Pendidikan (Bandung: Pustaka Setia, 2009), h. 226.
} 
Antara budaya dan akademik mempunyai hubungan erat karena budaya terbentuk dari proses belajar, sehingga keduanya tidak bisa dipisahkan antara satu dan yang lainnya. Selanjutnya proses pembelajaran juga memperhatikan dan menyerap unsur-unsur positif dari budaya yang berlaku dalam komponen masyarakat tempat proses belajar berlangsung. Keterkaitannya dapat dilihat pada landasan-landasan yang harus diperhatikan penyusunan kurikulum, metode mengajar, materi pelajaran,dan lain-lain salah satunya adalah landasan sosial budaya. ${ }^{18}$

Pengembangan budaya akademik merupakan sebuah upaya untuk membangun nilai-nilai dan norma-norma yang menampilkan suasana akademik, yaitu suasana yang sesuai nilai-nilai dan kaidah-kaidah ilmiah dalam upaya memperoleh dan mengembangkan pengetahuan dan mencari kebenaran. Suasana tersebut diperlukan, dipelihara, dan dibina di lembaga pendidikan. ${ }^{19}$ Pendidikan budaya akademik mengandung implementasi nilainilai seperti nilai-nilai moral, kebenaran, kejujuran, sehingga membangun suasana dan pelaku-pelaku akademis yang bermoral, bernilai kejujuran, kebenaran dalam pemikiran dan perbuatan.

Dalam perspektif pendidikan Islam, ada tiga dimensi nilai yang perlu dikembangkan dalam pendidikan. Pertama, dimensi spiritual yaitu keimanan, ketakwaan dan berakhlak, yang dimulai dalam implementasi kehidupan sehari-hari. Kedua, dimensi budaya yaitu kepribadian yang mapan dan mandiri serta bertanggung jawab kepada Allah, manusia dan lingkungannya. Ketiga, dimensi kecerdasan yang membawa kepada kemajuan dan perkembangan. Kecerdasan tersebut seperti kreatif, terampil, inovatif dan produktif. Ketiga dimensi ini saling berkaitan antara satu dengan yang lainnya. ${ }^{20}$

Adapun nilai-nilai yang perlu dikembangkan dalam budaya akademik dalam pendidikan adalah sebagaimana yang terdapat dalam tabel berikut ini: ${ }^{21}$

${ }^{18}$ Usman Mulyadi, Wirokusumo, Dasar-Dasar Pengembangan Kurikulum (Jakarta: Bina Aksara, 1988), h. 25-40.

${ }^{19}$ Lihat Menanti, Membangun Budaya Akademik.

${ }^{20}$ Said Aqil Husin al-Munawar, Aktualisasi Nilai-Nilai al-Qur'an dalam Pendidikan Islam (Jakarta: Ciputat Press, 2005), h. 7-10.

${ }^{21}$ Lihat Muhaimin, Pemikiran dan Aktualisasi Pengembangan Pendidikan Islam (Jakarta: RajaGrafindo Persada, 2011); Muhaimin Pedoman Sekolah, Pengembangan Pendidikan Budaya dan Karakter Bangsa (Jakarta: Puskur Kemendiknas, 2010). 
Tabel

Nilai-nilai Budaya dalam Pendidikan

\begin{tabular}{|c|c|c|}
\hline No & Nilai & Deskripsi \\
\hline 1 & Religius & Sikap dan perilaku yang patuh dalam menjalankan agama. \\
\hline 2 & Jujur & $\begin{array}{l}\text { Sikap dan perilaku yang selalu menjadikan dirinya dapat dipercaya baik } \\
\text { dalam perkataan, tindakan dan pekerjaan. }\end{array}$ \\
\hline 3 & Toleransi & $\begin{array}{l}\text { Sikap dan tindakan yang menghargai perbedaan agama, suku dan etnis, } \\
\text { pendapat, sikap dan tindakan orang lain yang berbeda dari dirinya. }\end{array}$ \\
\hline 4 & Disiplin & Perilaku tertib dan patuh pada berbagai ketentuan dan peraturan. \\
\hline 5 & Kerja keras & $\begin{array}{l}\text { Perilaku yang sungguh-sungguh dalam menghadapi berbagai hambatan } \\
\text { dalam belajar dan tugas serta menyelesaikannya dengan sebaik-baiknya. }\end{array}$ \\
\hline 6 & Kreatif & $\begin{array}{l}\text { Berpikir dan melakukan sesuatu untuk menghasilkan cara atau hasil yang } \\
\text { baru dari sesuatu yang telah dimilikinya. }\end{array}$ \\
\hline 7 & Mandiri & Sikap dan perilaku yang tidak mudah bergantung pada orang lain. \\
\hline 8 & Demokratis & $\begin{array}{l}\text { Cara berpikir, bersikap dan bertindak yang menilai sama hak dan kewajiban } \\
\text { dirinya dan orang lain. }\end{array}$ \\
\hline 9 & $\begin{array}{l}\text { Rasa ingin } \\
\text { tahu }\end{array}$ & $\begin{array}{l}\text { Sikap dan tindakan yang selalu berupaya untuk mengetahui lebih men- } \\
\text { dalam dan luas dari sesuatu yang dipelajari, dilihat dan didengar. }\end{array}$ \\
\hline 10 & $\begin{array}{l}\text { Semangat } \\
\text { kebangsaan }\end{array}$ & $\begin{array}{l}\text { Menempatkan kepentingan bangsa di atas kepentingan diri sendiri dan } \\
\text { kelompok. }\end{array}$ \\
\hline 11 & $\begin{array}{l}\text { Menghargai } \\
\text { prestasi }\end{array}$ & $\begin{array}{l}\text { Sikap dan tindakan yang mendorong dirinya untuk menghasilkan sesuatu } \\
\text { yang berguna bagi masyarakat dan mengakuinya serta menghormati keber- } \\
\text { hasilan orang lain. }\end{array}$ \\
\hline 12 & Komunikatif & $\begin{array}{l}\text { Tindakan yang memperlihatkan rasa senang berkomunikasi dan bekerja } \\
\text { sama dengan pihak lain. }\end{array}$ \\
\hline 13 & Cintai damai & $\begin{array}{l}\text { Sikap, perkataan, dan tindakan yang menyebabkan orang lain merasa } \\
\text { senang dan aman atas kehadirannya. }\end{array}$ \\
\hline 14 & $\begin{array}{l}\text { Gemar } \\
\text { membaca }\end{array}$ & $\begin{array}{l}\text { Kebiasaan menyediakan waktu untuk membaca dari berbagai sumber } \\
\text { untuk pengembangan dirinya. }\end{array}$ \\
\hline 15 & $\begin{array}{l}\text { Peduli } \\
\text { lingkungan }\end{array}$ & $\begin{array}{l}\text { Sikap dan tindakan yang selalu menjaga kebersihan lingkungan dan } \\
\text { mengembangkan upaya-upaya untuk memperbaiki kerusakan lingkungan. }\end{array}$ \\
\hline 16 & Peduli sosial & $\begin{array}{l}\text { Sikap dan tindakan yang selalu ingin memberikan bantuan kepada orang } \\
\text { lain dan masyarakat yang membutuhkan. }\end{array}$ \\
\hline 17 & $\begin{array}{l}\text { Tanggung } \\
\text { jawab }\end{array}$ & Melakukan tugas dan kewajibannya dengan sepenuh hati. \\
\hline
\end{tabular}

Nilai-nilai dalam pendidikan tersebut menjadi dasar untuk mengembangkan pendidikan dan menjadi budaya dalam pelaksanaan sehari-hari, sehingga tujuan pendidikan bisa tercapai. Pendidikan bertujuan tidak hanya sekadar proses alih budaya atau alih pengetahuan (transfer of knowledge), akan tetapi juga sekaligus proses alih nilai (transfer of value). Pendidikan Islam menjadikan manusia yang bertakwa manusia yang bisa mencapai kesuksesan hidup 
di dunia dan akhirat. ${ }^{22}$ Pendidikan merupakan suatu hal yang dibutuhkan oleh setiap orang, karena dengan adanya pendidikan akan membawa seseorang ke arah yang lebih baik sebagaimana ungkapan Zakiah Daradjat, "pendidikan adalah usaha yang dijalankan oleh seseorang atau sekelompok orang lain agar menjadi dewasa atau menjadi tingkatan hidup atau penghidupan yang lebih tinggi dalam arti mental." 23

Pimpinan sebuah lembaga pendidikan termasuk di dalamnya dayah harus mampu membangun suasana akademis dan menciptakan iklim pendidikan yang nyaman dan teratur untuk tercapainya tujuan pendidikan secara komperehensif. Demi terlaksananya pendidikan dengan baik, maka diperlukan penerapan budaya akademik secara sistematis, karena budaya akademik akan mengikat antara satu aspek pendidikan dengan aspek lainnya. Adapun ciri-ciri dari budaya akademik adalah sebagaimana yang terdapat pada tabel berikut ini.

Tabel

Ciri-ciri Budaya Akademik

\begin{tabular}{|c|l|l|}
\hline No & \multicolumn{1}{|c|}{$\begin{array}{c}\text { Budaya } \\
\text { Akademik }\end{array}$} & \multicolumn{1}{c|}{ Deskripsi } \\
\hline 1 & $\begin{array}{l}\text { Penghargaan ter- } \\
\text { hadap pendapat } \\
\text { orang lain secara } \\
\text { obyektif }\end{array}$ & $\begin{array}{l}\text { Menghargai pendapat orang lain tanpa membedakan kelompok, } \\
\text { suku dan agama. Jika pendapatnya benar maka akan diambil } \\
\text { sebagai sebuah rujukan dan jika salah akan dieavaluasi kembali. }\end{array}$ \\
\hline 2 & $\begin{array}{l}\text { Pemikiran rasional } \\
\text { dan kritis-analitis } \\
\text { dengan tanggung- } \\
\text { jawab moral }\end{array}$ & $\begin{array}{l}\text { Setiap persoalan yang muncul akan dianalisis secara rasional dan } \\
\text { dikaji ulang baik dari segi positif dan negatif atau dari segi halal dan } \\
\text { haram, sehingga bisa dipertangung jawabkan baik di hadapan manusia } \\
\text { maupun di hadapan Allah SWT. }\end{array}$ \\
\hline 3 & $\begin{array}{l}\text { Kebiasaan mem- } \\
\text { baca }\end{array}$ & $\begin{array}{l}\text { Membiasakan diri membaca dari berbagai sumber dan karangan } \\
\text { tanpa terikat oleh satu buku atau seorang pengarang. }\end{array}$ \\
\hline 4 & $\begin{array}{l}\text { Penambahan ilmu } \\
\text { dan wawasan }\end{array}$ & $\begin{array}{l}\text { Menambah ilmu dari berbagai bahan bacaan dan kajian sehingga } \\
\text { akan bertambah ilmu pengetahuan. }\end{array}$ \\
\hline 5 & $\begin{array}{l}\text { Kebiasaan meneliti } \\
\text { dan mengabdi } \\
\text { kepada masyarakat }\end{array}$ & $\begin{array}{l}\text { Membiasakan diri meneliti terhadap berbagai fenomena yang muncul } \\
\text { dalam masyarakat dan melakukan pengabdian. }\end{array}$ \\
\hline 6 & $\begin{array}{l}\text { Penulisan artikel, } \\
\text { makalah, buku }\end{array}$ & $\begin{array}{l}\text { Menulis ilmu yang sudah dimiliki atau diteliti dalam berbagai bentuk } \\
\text { baik dalam bentuk makalah, artikel, buku, opini dan lain-lain. }\end{array}$ \\
\hline 7 & $\begin{array}{l}\text { Diskusi ilmiah } \\
\text { Melakukan diskusi ilmiah untuk menambah wawasan dari berbagai }\end{array}$ \\
\hline 8 & $\begin{array}{l}\text { Proses belajar- } \\
\text { mengajar } \\
\text { partisipatif }\end{array}$ & $\begin{array}{l}\text { Proses belajar-mengajar berjalan dengan baik dari segi materi, metode, } \\
\text { sarana dan prasarana, dan evaluasi. }\end{array}$ \\
\hline
\end{tabular}

${ }^{22}$ Ahmad Syafii Maarif, et al, Pendidikan Islam di Indonesia: Antara Cita dan Fakta (Yogyakarta: Wacana Yogya, 1991), h. 44.

${ }^{23} Z$ akiah Daradjat, et al., Ilmu Pendidikan Islam (Jakarta: Bumi Aksara, 2008), h. 28. 


\begin{tabular}{|c|l|l|}
\hline 9 & $\begin{array}{l}\text { Manajemen yang } \\
\text { baik }\end{array}$ & $\begin{array}{l}\text { Manajemen pengelolaan berjalan dengan baik dari aspek struktur } \\
\text { organisasi, kepemimpinan dan program kerja dan tersedianya sarana } \\
\text { dan prasarana akademik yang memadai, seperti lingkungan kampus } \\
\text { yang sejuk, perpustakaan yang lengkap, dan laboratorium yang modern. }\end{array}$ \\
\hline 10 & $\begin{array}{l}\text { Tersedianya } \\
\text { sumber daya } \\
\text { manusia }\end{array}$ & $\begin{array}{l}\text { Tersedianya SDM yang memadai, salah satunya adalah pengajarnya } \\
\text { yang mempunyai kelebihan akademik dan mempunyai dedikasi tinggi } \\
\text { untuk pengembangan keilmuan dan menguasai tradisi akademik } \\
\text { yang unggul, seperti kemampuan menyusun kurikulum yang aktual, } \\
\text { realistik, dan berorientasi ke depan. Pengajarannya melalui proses } \\
\text { belajar-mengajar dialogis, bebas, dan objektif, dan kemudian dikem- } \\
\text { bangkan dalam bentuk diskusi, seminar, penelitian, penerbitan buku } \\
\text { dan jurnal ilmiah, yang disebarluaskan kepada masyarakat. }\end{array}$ \\
\hline
\end{tabular}

Budaya akademik merupakan suasana pendidikan dalam masyarakat ilmiah yang beranekaragam, majemuk, multikultural dalam sebuah institusi yang mendasarkan diri pada nilai-nilai kebenaran ilmiah dan objektivitas. Budaya akademik dibangun berdasarkan prinsip kebebasan berpikir, berpendapat dan mimbar akademik yang dinamis, terbuka serta ilmiah. Keterlibatan akademik dalam pelaksanaan proses belajar-mengajar merupakan faktor yang penting dalam meningkatkan prestasi belajar. Visi pimpinan lembaga pendidikan dan iklim akademik dapat mendorong guru dalam memanfaatkan lebih banyak waktu untuk kegiatan belajar, membimbing siswa agar mempergunakan waktunya untuk belajar. ${ }^{24}$

Ada beberapa tipologi yang harus dikembangkan dalam budaya akademik. Karena budaya akademik muncul dari sebuah proses panjang yang meliputi berbagai kegiatan akademik yang terencana secara sistematis. Proses interaksi yang dilakukan secara terus menerus antar unsur akademik akan melahirkan suatu perilaku, tradisi dan budaya ilmiah di dalam masyarakatnya. Untuk melihat tipologi dalam budaya, maka ada tiga hal yang berkaitan dengan budaya yaitu budaya sebagai simbol-simbol atau slogan, budaya sebagai tingkah laku, gerak gerik yang muncul akibat slogan, atau motto yang ditanamkan dan budaya sebagai kepercayaan yang tertanam dan mengakar serta menjadi acuan dalam bertindak dan bertingkah laku. ${ }^{25}$

Dalam membuat tipologi budaya akademik, akan dibatasi kepada empat hal, yakni budaya memberi pendapat, budaya belajar, budaya pengembangan keilmuan dan budaya organisasi. Pengelompokan ini didasari pada pembagian ciri-ciri budaya akademik yang ditulis oleh Kistanto dan Kurniawan.

Budaya akademik sebagai sistem dan tata nilai memegang peranan penting dalam pengembangan pendidikan yang memerlukan usaha dalam menciptakan budaya akademik melalui berbagai kegiatan seperti membaca, meneliti dan menulis. Budaya akademik tidak h. 104.

${ }^{24}$ Jamaluddin Idris, Sekolah Efektif dan Guru Efektif (Banda Aceh: Taufiqiyah Sa'adah, 2006),

${ }^{25}$ Lihat Koentjaraningrat, Pengantar Ilmu Antropologi (Jakarta: Rineka Cipta, 2002). 
hanya bertujuan untuk meningkatkan intelektual, akan tetapi juga kejujuran, kebenaran dan pengabdian kepada kemanusiaan, sehingga secara keseluruhan budaya akademik adalah budaya dengan nilai-nilai karakter positif. Dalam pengembangan budaya akademik ada beberapa tipologi yang perlu dikembangkan dalam pendidikan, antara lain budaya belajar, budaya pengembangan keilmuan, budaya memberi pendapat, dan budaya berorganisasi.

\section{Budaya Akademik di Dayah Salafiyah}

Dayah adalah satu lembaga pendidikan Islam yang tertua di Aceh. Lembaga pendidikan ini sama seperti lembaga pendidikan pesantren yang ada di Jawa, baik dari aspek fungsi maupun tujuannya. Dayah merupakan suatu tempat yang dipersiapkan untuk memberikan pendidikan agama mulai dari tingkat dasar sampai ke tingkat belajar yang tinggi. ${ }^{26}$ Dayah adalah lembaga pendidikan lanjutan bagi anak-anak yang sudah menyelesaikan pendidikan dasar di surau atau di rumah-rumah guru. ${ }^{27}$

Dayah berasal dari bahasa Arab yaitu zawiyah yang berarti sudut atau pojok masjid yang digunakan untuk iktikaf, ${ }^{28}$ dimana musafir yang umumnya sufi berzikir, bertemu, belajar dan bertukar pengalaman sesama mereka. Menurut Yusny Saby, tradisi tersebut berkembang ke berbagai kelompok di seluruh dunia. Dalam perjalanan sejarah selanjutnya, terutama ketika sampai di Aceh, dari zawiyah menjadai zayah, dan dayah yang arti dan fungsinya juga mengalami metamorfosa, di samping sebagai tempat kegiatan agama juga sebagai tempat belajar yang layaknya sebagai lembaga pendidikan formal. Keberadaan dayah sebagai lembaga pendidikan erat kaitannya dengan masjid, yang lokasinya ada di setiap mukim. Masjid menjadi identitas sebuah kemukiman dan dikepalai oleh seorang imam kemukiman.

Kata dayah juga sering diucapkan deyah oleh masyarakat Aceh Besar, yang diambil dari bahasa Arab zawiyah yang bermakna sebuah sudut yang diyakini oleh masyarakat Aceh pertama kali digunakan di sudut masjid Madinah ketika Nabi Muhammad SAW. berdakwah pada masa awal Islam. ${ }^{29}$ Sedangkan di Sumatera Barat disebut dengan surau. Meskipun semua istilah tersebut mempunyai titik persamaan, namun jika ditelusuri secara mendalam akan didapati perbedaan-perbedaan di antara ketiga istilah tersebut. ${ }^{30}$

Sistem pendidikan yang berlangsung di dayah dapat dilihat dari lima aspek, yaitu

\footnotetext{
${ }^{26}$ Abdurrahman Saleh, Penyelenggara Pendidikan Formal di Pondok Pesantren (Jakarta: Dirjen Bimbaga Islam Departemen Agama RI., 2005), h.11.

${ }^{27}$ Ali Hasjmy, Sejarah Kebudayaan Islam di Indonesia (Jakarta: Bulan Bintang, 2005), h. 192.

${ }^{28}$ Ali al-Jumbulati 'Abd al-Futûh al-Tuwanisi, Perbandingan Pendidikan Islam, terj. M. Arifin (Jakarta: Rineka Cipta, 1994), h. 33.

${ }^{29}$ M. Hasbi Amiruddin, Ulama Dayah: Pengawal Agama Masyarakat Aceh (Lhokseumawe: Nadiya Foundation, 2003), h. 33.

${ }^{30}$ Haidar Putra Daulay, Historitas dan Eksistensi Dayah Sekolah dan Madrasah (Yogyakarta: Tiara Wacana Yogya, 2001), h. 9.
} 
tujuan pendidikan, pendidik (teungku), peserta didik (santri), materi ajar (kitab kuning), metode, sarana dan prasarana (asrama dan masjid). Sebagaimana telah dikemukakan sebelumnya bahwa dayah merupakan institusi pendidikan yang berusaha mentransfer nilai-nilai Islam tradisional yang berbasis pada turast (warisan) klasik berupa kitab kuning, dan dayah merupakan sentral penyelenggaraan pendidikan agama Islam. ${ }^{31}$

Sistem pendidikan yang diterapkan pada dayah ini adalah salaf murni atau tradisional murni, karena sistem tradisional murni ini diyakini mampu mempertahankan proses transformasi keilmuan dari kitab-kitab yang digunakan di seluruh dayah dan untuk mempertahankan regenerasi keulamaan.

Budaya akademik di dayah pernah berkembang pada masa dahulu terutama pada periode klasik (Abad Pertengahan). Pada masa tersebut telah muncul budaya akademik dalam aspek pemahaman ayat-ayat al-Qur'an dengan cerdas dan telah berusaha keras untuk mengaplikasikannya dalam realita kehidupan dengan menghasilkan banyak karya dan pemikirannya. Kitab-kitab yang dibaca di dayah sekarang seperti Bajuri dan Mahalli dalam ilmu fikih, dan Ihyâ 'Ulûm al-Dîn dalam bidang tasawuf, adalah bahagian dari kitabkitab produk periode Abad Pertengahan. Untuk itulah pimpinan dayah, pendidik, pengelola dayah dan santri perlu dibekali pemahaman konsep tentang budaya akademik. Dengan memahami konsep budaya akademik, serta mengembangkannya di dayah akan menghasilkan perkembangan dayah yang lebih baik dan lebih siap dalam menghadapi perkembangan zaman. Sebab itu, pengembangan budaya akademik di dayah merupakan hal yang penting dan berpengaruh dalam membentuk profesionalitas pelaku pendidikan yang bernilai agama dan berbudaya. Dengan demikian, budaya akademik di dayah dapat dikatakan berkembang apabila dilakukan secara komprehensif baik dari segi sarana dan prasarana juga penataan lingkungan dayah yang kondusif, dan proses pembelajaran berjalan baik.

Suasana akademis yang dinamis, penuh kekeluargaan, kerjasama serta saling menghargai akan menjadi sumber inspirasi dan kekuatan untuk mengembangkan sebuah lembaga pendidikan termasuk dayah. Pengembangan tersebut dilakukan baik dari sisi spiritual, intelektual, profesional, atau sebaliknya. Jika sebuah lembaga pendidikan dibangun dengan suasana akademik yang tidak harmonis, saling mencurigai dan tidak menghargai di antara sesama, maka akan melemahkan dan akan membuat lembaga pendidikan tersebut tidak akan bisa bertahan lama.

Budaya akademik tidak hanya bertujuan untuk meningkatkan intelektual, tetapi juga kejujuran, kebenaran dan pengabdian kepada kemanusiaan, sehingga secara keseluruhan mengembangkan budaya dengan nilai-nilai karakter positif. Nilai-nilai akademik merupakan hasil dari proses belajar dan latihan. Hal tersebut dapat dilakukan oleh masyarakat atau individu sebagai bagian dari lingkungan akademik melalui rekayasa faktor lingkungan.

\footnotetext{
${ }^{31}$ Nurcholish Madjid, Bilik-Bilik Pesantren: Sebuah Potret Perjalanan (Jakarta: Madina, 1997), h. 16 .
} 
Di antaranya, dapat dilakukan melalui strategi yang meliputi keteladanan, intervensi, pembiasaan yang dilakukan secara konsisten, dan penguatan. ${ }^{32}$

Berkembang atau tidaknya budaya akademik di dayah dipengaruhi oleh nilai-nilai yang berkembang di dayah dan menjadi pegangan dalam menjalankan roda pendidikan di dayah. Setelah dilakukan penelitian, diperoleh gambaran terhadap perkembangan budaya akademik di dayah salafiyah Aceh Besar, yang meliputi budaya belajar, memberi pendapat, budaya pengembangan keilmuan, dan budaya berorganisasi di dayah Salafiyah Aceh Besar.

Dari hasil penelitian ditemukan bahwa budaya akademik di dayah salafiyah masih belum berkembang sebagaimana mestinya. Hal ini disebabkan oleh beberapa faktor. Pertama, budaya akademik di dayah didapati secara turun temurun (budaya dari satu dayah diwariskan kepada dayah berikutnya). Kedua, dayah masih menggunakan kurikulum yang tradisional yang berisikan tentang hukum Islam (fikih) yang bersumber dari mazhab Syâfiî̀, teologi (ilmu tauhid) yang berpegang pada aliran Asy'ariyah, tasawuf berpegang pada pendapat al-Ghazâlî, dan menggunakan bahasa Arab/Jawi. Mata pelajaran tersebut dipelajari dari kitab kuning, yaitu kitab-kitab yang ditulis oleh ulama salaf pada masa dahulu, sehingga pembatasan kurikulum dayah pada materi dan aliran tertentu tidak memberikan kesempatan kepada santri untuk memperluas cakrawala keilmuan dan tidak memiliki kebebasan berpikir. Ketiga, metodologi pengajaran yang digunakan di dayah masih tradisional seperti drah dan halaqah sehingga proses pembelajarannya berjalan pasif, dan menimbulkan kejenuhan dalam belajar. Keempat, organisasi dayah belum dikelola dengan manajemen yang sistematis, roda organisasi dayah tergantung kepada pimpinan dayah, karena pimpinan dayah merupakan pengambil kebijakan utama dan mempunyai hak otoritas yang tinggi. Hal ini berpengaruh pada tidak berjalannya manajemen organisasi dengan baik karena semua keputusan tergantung kepada pimpinan dayah, faktor-faktor tersebut berpengaruh pada perkembangan budaya akademik yang meliputi budaya belajar, budaya memberi pendapat, pengembangan keilmuan, dan budaya berorganisasi.

\section{Budaya Belajar pada Dayah Salafiyah Aceh Besar}

Budaya belajar dalam pendidikan dayah adalah kebiasaan-kebiasaan yang berlaku di dayah sehingga mempengaruhi santri dalam usaha memperoleh ilmu pengetahuan, kecakapan, keterampilan, dan pembentukan sikap selama mereka berada dalam komunitas dayah.

Berikut ini kegiatan-kegiatan yang berlangsung di dayah. Pertama, pagi, salat subuh berjamaah, diikuti zikir dan ceramah serta belajar sampai dengan matahari terbit. Kedua, setelah mandi dan sarapan dilanjutkan kembali dengan belajar di tempat yang telah ditentukan seperti bale, rangkang atau masjid sampai menjelang Zuhur. Ketiga, makan siang dilanjutkan

${ }^{32}$ Darmiyati Zuchdi, et al. Pendidikan Karakter dengan Pendekatan Komprehensif: Terintegrasi dalam Perkuliahan dan Pengembangan Kultur Universitas (Yogjakarta: UNY Press, 2010), h. 29. 
dengan salat Zuhur dan belajar sampai dengan Asar. Keempat, setelah Asar santri istirahat atau melakukan olah raga. Kelima, salat Maghrib berjamaah dan dilanjutkan dengan zikir. Keenam, kemudian dilanjutkan dengan belajar di kelas atau tempat yang telah ditentukan, sampai dengan salat Isya. Ketujuh, setelah salat Isya, di antara santri ada yang belajar di ruangan dan ada juga yang mengulang materi yang telah diberikan pada santri senior (pendidik/teungku rangkang). Kedelapan, kegiatan ini dilakukan secara berkelanjutan. Kesembilan, kegiatan lainnya adalah kegiatan ektrakurikuler seperti gotong royong pada hari Jumat, dalâ’il al-khairât (kitab barzanji) dan belajar berpidato (muhadharah) pada setiap malam Jumat.

Pendidik memberikan ilmunya kepada santri serta menurunkan sifat-sifat terpuji kepadanya. Teungku menjelaskan isi kitab dan menceritakan kisah-kisah mendidik baik cerita pengalaman pribadi, $S$ îrah Nabawiyah, ataupun kisah-kisah lain yang dapat memberikan motivasi dan semangat untuk santri belajar di dayah.

Pendidik menanamkan keyakinan kepada santri bahwa mengajar ilmu kepada orang lain, menjadi khatib pada hari Jumat, hari Raya Idul Adha dan Idul Fitri, menjadi imam terawih pada bulan Ramadhan merupakan kewajiban bagi seorang santri. Teungku tidak hanya memberi ilmu, akan tetapi juga membimbing dan bahkan bertanggungjawab sepenuhnya terhadap kehidupan santri terutama ketika berada di dayah.

Ada beberapa tempat yang digunakan santri untuk belajar di dayah. Pertama, belajar dalam ruangan, santri belajar di ruangan yang telah ditentukan beserta seorang pendidik/ teungku. Santri membawa kitab ke dalam ruangan sesuai dengan jadwalnya, santri mempelajari isi kitab sesuai dengan arahan dan bimbingan pendidik/teungku. Selanjutnya diperlancar bersama santri lainnya. Kedua, rangkang/bale, kegiatan di bale selain digunakan sebagai tempat mengaji. Bale juga digunakan sebagai tempat mempraktikkan cara beribadah. Setelah pendidik/teungku menjelaskan materi kemudian santri mempraktikkannya dan selanjutnya mereka mengikutinya. Ketiga, kamar, santri melakukan pengulangan dan hapalan yang sudah diajarkan di kamar masing-masing yang juga mendapat pengawasan pendidik/ teungku atau asisten teungku bahkan sesama santri. Keempat, masyarakat, santri dituntut untuk memberikan ilmunya kepada masyarakat (bagi yang sudah mampu) sehingga banyak ditemui pengajian yang dipimpin oleh santri dayah di desa-desa. Di samping itu, santri sering mendapat undangan untuk memberikan ceramah dan pengajian kitab-kitab, bahkan menjadi pemimpin pelaksanaan salat jenazah dalam masyarakat.

Budaya belajar di dayah dilandasi atas keikhlasan dan hanya mengharap rida dari Allah SWT. Pimpinan dayah, tenaga pengajar dan santri dalam melaksanakan pengajian didorong oleh niat yang tulus dan hati yang ikhlas. Pendidikan dayah tidak mengejar simbolsimbol seperti sertifikat atau ijazah, melainkan untuk mendapatkan ilmu dan rida dari Allah SWT. dan teungkunya, serta berakhlak mulia. Belajar di dayah dijalankan tidak hanya mentrasfer ilmu agama, akan tetapi juga menstranfer keteladanan dari teungku chiek/pimpinan dayah. Dalam proses belajar dan mengajar mereka tidak hanya termotivasi untuk mendapatkan 
ilmu atau menyampaikan ilmu, akan tetapi juga didorong oleh sebuah kewajiban yang harus dilaksanakan dan sebagai amanah yang harus dijalankan.

Motivasi agama dan kehidupan akhirat menjadi faktor pendukung terciptanya suasana sakral dalam proses belajar dan mengajar. Teungku dalam mengajar dan santri ketika belajar meyakini bahwa sedang menjalankan ibadah. Keyakinan tersebut membawa pengaruh kepada teungku dan santri serius dan konsentrasi dalam proses belajar-mengajar. Belajar di dayah dilakukan secara komprehensif antara pemahaman keilmuan dan praktik ibadah. Belajar di dayah tidak bersifat transaksional. Artinya, mereka tidak melakukan proses transaksi dalam pengajaran, sehingga tidak ada penentuan standar bayaran atau gaji setelah selesai mengajar, hubungan antara tenaga pengajar dengan santri terjalin dengan baik dalam suasana kebersamaan dan ukhuwah al-Islâmiyah. Teungku memperhatikan kehidupan santri di dayah dan memberikan perhatian penuh kepada santri. Pimpinan dayah dan tenaga pengajar di dayah menjadi teladan dalam kehidupan santri. Di samping itu juga rajin membaca bahkan menghapal kitab kuning yang menjadi pegangan dalam pengajiannya.

Kelebihan lain dari budaya belajar di dayah adalah jika ada santri yang melanggar aturan atau ketetapan yang sudah ditetapkan oleh teungku, maka akan diberikan hukuman. Akan tetapi, hukuman tersebut tidak membawa dampak dendam dari santri kepada yang menjatuhkan hukuman kepadanya, kebencian atau sikap-sikap negatif lainnya. Santri mempercayai bahwa setiap pukulan atau hukuman yang diberikan tenaga pengajar/ustaz, maka akan membawa berkah bahkan akan menjadi pelindung dari api neraka. Dayah selektif dalam memilih tenaga pengajar karena harus mengalami proses yang panjang dimulai dari profesionalisme, kecerdasan, sikap, dan perilaku, ketekunan dalam melaksanakan ibadah serta loyalitas dan dedikasi yang tinggi. Untuk seorang teungku yang akan mengajarkan kitab kuning dituntut untuk benar-benar menguasai materi yang akan disampaikan kepada santri secara profesional.

Dalam budaya belajar di dayah juga terdapat beberapa kekurangan. Pertama, santri menerima apa adanya dari teungku dengan tidak mencari sumber dari yang lain. Kedua, fanatik yang berlebihan kepada teungku, mereka menerima yang disampaikan oleh tenaga pengajar dan berpegang teguh serta menjadi pedoman dalam hidup. Ketiga, belum ada keseimbangan antara pendidikan agama dengan pendidikan umum. Keempat, belum mampu merespons dan beradaptasi dengan perkembangan zaman. Kelima, tidak memiliki planning yang terperinci dan rasional dalam proses belajar-mengajar. Keenam, kurikulum tidak disusun secara sistematis dan tidak menyesuaikan dengan kebutuhan lapangan. Ketujuh, sistem pemberian materi masih bersifat tradisional (drah, halaqah dan hapalan). Kedelapan, tidak adanya prioritas antara materi yang satu dengan materi yang lain, fokus materi belajar kepada ilmu fikih, tasawuf dan ilmu alat (nahu dan saraf). Kesembilan, kurangnya penekanan pada aspek membaca dan menulis. Kesepuluh, santri hanya membaca kitab kuning yang diberikan oleh teungkunya dan tidak membaca kitab Islam lainnya yang ditulis oleh ulamaulama kontemporer. Kesebelas, dayah masih kurang memperhatikan kebersihan di lingkungannya. 


\section{Budaya Memberi Pendapat pada Dayah Salafiyah}

Memberi pendapat merupakan hak semua orang termasuk santri yang sedang mengikuti proses pendidikan. Memberi pendapat biasanya dilakukan dalam rapat, diskusi dan pengajian. Memberi pendapat di dayah berbeda dengan memberi pendapat di lembaga pendidikan lainnya, seperti sekolah dan perguruan tinggi. Memberi pendapat di dayah terikat dengan aturan etika dan nilai-nilai yang ada di dayah karena di dayah mempunyai peraturan sendiri yang berbeda dengan lembaga lain. Budaya memberi pendapat di dayah biasanya disampaikan dalam materi pelajaran tertentu, tidak dapat diterapkan pada semua materi pelajaran.

Dalam memberi pendapat santri berhati-hati dan menyampaikannya dengan sopan santun serta tidak berani membantah sesuatu yang disampaikan oleh teungkunya. Santri takut menyakiti atau tersinggung hati teungkunya. Tidak semua mata pelajaran santri boleh memberi pendapat atau berdiskusi, bertanya atau menyampaikan idenya setelah mendapatkan izin dari ustaz/teungku. Santri mematuhi segala aturan yang telah ditetapkan di dayah dan tidak melakukan sesuatu yang melanggar aturan yang ada di dayah karena menurut mereka jika melanggar hukumannya bukan hanya di dunia akan tetapi juga di akhirat. Dalam mengikuti proses pembelajaran di dayah, santri diajarkan dan dituntut untuk berakhlak mulia, patuh dan tunduk kepada tenaga pengajar, tidak boleh membantah.

Kelebihan lainnya adalah santri dalam berbicara atau memberikan pendapat dengan sopan dan suara lemah lembut. Jika teungku sedang berbicara, mereka tidak berani membantah atau menunjukkan sikap yang tidak menyenangkan di depan teungkunya. Biasanya santri menganguk-anggukkan kepalanya tanda mereka memahami apa yang disampaikan serta tidak berani memberi komentar jika tidak diminta.

Adapun kekurangan dalam penerapan budaya memberi pendapat di dayah adalah proses belajar-mengajar secara monolog (one way traffic); seorang teungku mentransfer ilmunya kepada santrinya dengan membacakan dan menterjemahkan serta memberi komentar atas kitab yang dikajinya, sedangkan santri hanya mendengar sambil mencatat makna harfiahnya dan memberikan simbol-simbol i'rab (kedudukan kata dalam struktur kalimat); berdasarkan pada aturan yang telah dirancang sedemikian rupa, santri tidak akan berani membantah atau bertanya jika tidak diberi izin oleh teungkunya dan penekanan pada aspek hapalan pada setiap materi pelajarannya.

\section{Budaya Pengembangan Keilmuan pada Dayah Salafiyah}

Membangun budaya akademik dalam suatu lembaga pendidikan membutuhkan proses yang panjang, diperlukan perencanaan dan sosialisasi terhadap kegiatan akademik, sehingga menjadi kebiasaan di kalangan akademisi untuk melakukan norma-norma akademik dalam kegiatan proses pendidikan. Tanpa melakukan kegiatan-kegiatan akademik, sulit bagi seorang akademisi untuk memperoleh nilai-nilai normatif akademik. Sebagai sebuah lembaga pendidikan dayah yang telah menghasilkan alumni yang handal dan berperan 
aktif dalam pengembangan masyarakat terutama yang berkaitan dengan pendidikan. Pendidikan di dayah selain berfungsi sebagai benteng dalam masyarakat juga berfungsi sebagai pusat pengembangan keilmuan.

Kehadiran dayah berarti bagi santri dan masyarakat karena pendidikan di dayah tidak hanya membina santri dengan pendidikan akidah, ibadah dan akhlak mulia, akan tetapi juga dayah terlibat langsung dalam kegiatan kemasyarakatan seperti kegiatan fardhu kifayah, kegiatan Ramadan dan pengajian dalam masyarakat. Kepedulian pendidik/teungku selain dalam proses belajar-mengajar dan ibadah, juga mengajarkan cara menyampaikan ilmu kepada masyarakat. Sebab santri ini adalah cikal bakal penerus dan ujung tombak yang akan membantu masyarakat dalam menyelesaikan hukum-hukum yang berkaitan dengan pelaksanaan ibadah, dan munakahah.

Dalam pengembangan keilmuan di dayah, pendidikannya meliputi pada tiga aspek. Pertama, aspek ibadah untuk menanamkan keimanan dan ketauhidan. Kedua, tabligh untuk penyebaran keilmuan dan pengabdian. Ketiga, amalan untukmewrjudkan kegiatan kemasyarakatan. Orientasi keilmuan lebih difokuskan pada kajian-kajian ilmu terapan seperti fikih, tasawuf dan ilmu alat (nahu dan saraf), santri berkeyakinan bahwa segala sesuatu yang diajarkan oleh teungku diterima sebagai kebenaran hakiki dan tidak perlu analisa lebih lanjut sistem evaluasi yang bersifat self evaluation yang memungkinkan teungku melakukan penilaian secara lebih objektif dan melalui self evaluation santri dapat mengukur sendiri hasil belajarnya dan dapat menghindari kecurangan dalam ujian.

Tenaga pengajar/teungku memberikan motivasi kepada santri supaya melakukan tranformasi ilmu kepada orang lain, santri merupakan penyambung tranformasi ilmu dari ustad/teungku, karena santri akan berperan menjadi alumni, pengajar majelis taklim dalam masyarakat dan sebagai penceramah, sehingga alumni santri akan mendirikan dayah di tempatnya untuk mewariskan ilmu yang telah diterimanya dari teungkunya. Ilmu yang telah diberikan oleh teungkunya dipahami secara mendalam bahkan mereka mampu menghapalnya setiap isi dari kitab kuning.

Ada beberapa kekurangan dari pengembangan keilmuan di dayah. Santri hanya mendalami ilmu yang telah diberikan. Santri belum berani mengembangkan ilmu dengan perspektif lain atau dari referensi lain selain dari kitab kuning yang dipelajarinya. Santri hanya membaca atau mengulang kitab yang sudah diberikan sesuai dengan arahan dan bimbingan teungkunya. Proses pembelajaran yang terkesan statis terutama dalam metodologi dan materinya. Kitab yang diajarkan adalah kitab-kitab Abad Pertengahan. Secara keseluruhan metode dan materinya tidak ada perubahan sejak zaman dahulu, hanya terdapat pengulangan. Kitab-kitab klasik (kitab kuning) yang dijadikan rujukan utama adalah buku teks yang ditulis pada Abad Pertengahan dengan konteks masalah yang terjadi pada masa dahulu, sehinga jika muncul persoalan kekinian akan mengalami kesulitan dalam menyelesaikannya. 


\section{Budaya Organisasi pada Dayah Salafiyah di Aceh Besar}

Budaya akademik tidak hanya bertujuan untuk meningkatkan intelektual, tetapi juga kejujuran, kebenaran dan pengabdian kepada kemanusiaan, sehingga secara keseluruhan mengembangkan budaya dengan nilai-nilai karakter positif. Nilai-nilai akademik merupakan hasil dari proses belajar dan latihan. Hal tersebut dapat dilakukan oleh masyarakat atau individu sebagai bagian dari lingkungan akademik melalui rekayasa faktor lingkungan.

Meningkatkan mutu pendidikan dalam sebuah lembaga pendidikan berbeda dengan meningkatkan mutu di perusahaan. Peningkatan mutu dalam sebuah lembaga pendidikan memerlukan academic culture dan academic atmosphere, sedangkan dalam perusahaan diperlukan corporate value. Budaya akademik tidak dapat tumbuh semata-mata dari peraturan atau regulasi yang dibuat, akan tetapi berakar pada norma dan nilai ilmiah (scientific norms and values).

Dayah/pesantren sebagai sebuah lembaga pendidikan telah memainkan peranannya yang penting dalam perjuangan merebut kemerdekaan dan membina serta memajukan bangsa. Dayah sampai dengan masa sekarang ini masih bisa bertahan, walaupun ada sebagian telah tergusur dan berubah menjadi dayah terpadu. Masa depan dayah ditentukan oleh sejauh mana dayah mampu menformulasikan dirinya menjadi dayah yang mampu menyesuaikan diri dengan tuntutan zaman, tanpa menghilangkan jati dirinya dan kekhasannya sebagai dayah tradisional. Kemampuan adaptatif dayah atas perkembangan zaman akan memperkuat eksistensinya sekaligus menunjukkan keunggulannya.

Dayah juga mempunyai manajemen organisasi tersendiri. Budaya organisasi yang berkembang di dayah berbeda dengan budaya organisasi yang berkembang di lembaga pendidikan lainnya. Di dayah, pimpinan utamanya berada pada teungku dayah. Manajemen merupakan kemampuan dan keterampilan yang dilakukan secara bersama-sama untuk mencapai suatu tujuan yang telah ditentukan. Dalam pelaksanaan manajemen dayah, pengurusnya terdiri atas pimpinan dayah (teungku chiek), teungku, dan pengelola dayah. Masing-masing mereka mempunyai hak dan tanggung jawab dalam mengelola dayah. Pentingnya kepemimpinan dalam organisasi dayah karena pimpinan dayah merupakan tokoh utama dalam mengelola sebuah organisasi. Pemimpin mempunyai otoritas mengatur, mengelola dan memerintahkan anggotanya.

Sistem organisasi dayah sepenuhnya berada pada pimpinan dayah dayah. Pimpinan dayah adalah pendiri, pengelola, pengasuh, pemimpin, dan bahkan pemilik tunggal institusi dayah. Dalam pengelolaan organisasi dayah sikap kekeluargaan, keakraban, tolong-menolong ditekankan oleh pimpinan dayah karena nilai-nilai tersebut efektif untuk menjalin ikatan emosional antara tenaga pengajar, pengurus dayah dan santri dalam organisasi dayah secara keseluruhan. Organisasi dayah mampu terlaksana dengan baik walaupun tidak didukung oleh pendanaan atau struktur organisasi yang lengkap karena terjalin hubungan yang dekat antara tenaga pengajar dengan santrinya, kepatuhan santri pada tenaga pengajar 
tinggi, menjalankan organisasi dalam dayah dengan sederhana, organisasi di dayah berjalan secara mandiri tanpa terikat dengan pihak lain, Adanya sikap tolong menolong dalam pengelolaan dayah sehingga dayah akan tetap bertahan dalam kondisi apapun.

Adapun kekurangan dalam budaya organisasi dayah adalah roda organisasi. Berjalan atau tidaknya organisasi dayah tergantung kepada pimpinan dayah karena pimpinan dayah merupakan top leader, sehingga segala keputusan ada di tangannya, dan perjalanan dayah ada fase naik turun sesuai dengan kemampuan pimpinan dayah. Kemudian, tidak adanya pembagian tugas atau job description dalam struktur organisasi dayah, selain program kerja organisasi dayah tidak disusun secara terperinci, belum membenahi sistem administrasi, dan sistem peralihan kepemimpinan. Selama ini, proses suksesi atau peralihan kepemimpinan pada dayah berdasarkan keturunan. Artinya, pimpinan dayah tidak digantikan oleh orang lain yang tidak memiliki hubungan darah atau keluarga dengan pimpinan sebelumnya dan suksesi atau proses peralihan kepemimpinan seperti ini tidak selamanya berimplikasi konstruktif.

Untuk mengembangkan kembali budaya akademik di dayah, ada beberapa cara yang dapat dilakukan. Pertama, meningkatkan partisipasi dan komunikasi dengan semua stakeholder. Untuk meningkatkan partisipasi masyarakat dayah juga perlu membuat komite dayah yang terdiri atas wali palabah, masyarakat sekeliling dayah, dunia usaha dan dunia industri (DUDI), dan juga dayah diperlukan komunikasi dengan semua pihak seperti pemerintah daerah dan pemerintah provinsi, kantor pembinaan pendidikan dayah, dinas pendidikan, kementerian agama, dan dinas syariat Islam, dan perguruan tinggi negeri maupun perguruan tinggi swasta.

Kedua, melakukan pengembangan terstruktur. Dayah perlu melakukan pengembangan secara terstruktur dengan tidak menghilangkan tradisi yang sudah ada. Pengembangan tersebut bisa dilakukan melalui inovasi kurikulum dan metode pengajaran, mengembangkan sarana dan prasarana dayah, meningkatkan kualitas pendidik dan pelayanan pendidikan, mengoptimalisasi fungsi organisasi dayah sebagai wahana pengembangan diri, mengembangkan sikap saling menghargai antara satu dengan yang lain dan memberikan penghargaan terhadap kebebasan akademik, mempelajari kitab-kitab lain yang berkaitan dengan pendidikan agama selain kitab kuning, menghilangkan fanatisme yang berlebihan, dan menumbuhkembangkan budaya membaca dan budaya menulis serta memperbanyak diskusi ilmiah, seminar atau pelatihan untuk pengembangan wawasan keilmuan.

Ketiga, peningkatan sumber daya manusia (SDM). Selain mengembangkan diri secara kuantitas, dayah juga harus mengembangkan diri secara kualitas. Peningkatan SDM di dayah dapat dilakukan melalui beberapa cara antara lain melalui program magang dan pertukaran tenaga pengajar, pengelola dayah dan santri antara satu dayah dengan dayah lainnya, mengembangan santri dan alumninya dengan berbagai bentuk kegiatan seperti pelatihan, workshop atau lokakarya, di samping itu juga dayah perlu mengembangan santri dan alumninya dengan berbagai bentuk kegiatan seperti pelatihan, workshop atau 
lokakarya, dan berbagai bentuk kajian lainnya yang memberikan kontribusi besar dalam pengembangan SDM.

\section{Kesimpulan dan Saran}

Dayah merupakan bagian tidak terpisahkan dari tradisi masyarakat Aceh. Keberadaan dayah memiliki sejarah yang panjang, mengakar kuat masyarakat, baik dalam pola kehidupan sosial, budaya dan keagamaan. Penerapan budaya akademik di dayah menjadi sebuah keharusan dalam rangka pengembangan ilmu keagamaan dan wawasan keilmuan santri. Dari hasil penelitian didapati bahwa budaya akademik di dayah salafiyah masih belum berkembang sebagaimana mestinya. Hal ini disebabkan oleh beberapa faktor. Pertama, budaya akademik di dayah didapati secara turun temurun (budaya dari satu dayah diwariskan kepada dayah berikutnya). Kedua, dayah masih menggunakan kurikulum yang tradisional. Ketiga, metodologi pengajaran yang digunakan di dayah masih tradisional, Keempat, organisasi dayah belum dikelola dengan manajemen yang sistematis. Faktor-faktor tersebut berpengaruh pada budaya akademik dalam sistem pendidikan dayah yang meliputi budaya belajar, budaya memberi pendapat, pengembangan keilmuan, dan budaya berorganisasi.

Untuk mengembangkan kembali budaya akademik di dayah, ada beberapa cara yang dapat dilakukan. Pertama, meningkatkan partisipasi dan komunikasi dengan semua stakeholder. Kedua, melakukan pengembangan terstruktur. Ketiga, peningkatan sumber daya manusia (SDM). Perubahan tersebut perlu dilakukan karena tuntutan masyarakat dan dunia kerja, dan tuntutan modernisasi dan globalisasi.

\section{Pustaka Acuan}

Al-Munawar, Said Aqil Husein. Aktualisasi Nilai-Nilai al-Qur'an dalam Pendidikan Islam. Jakarta: Ciputat Press, 2005.

Al-Tuwanisi, 'Ali al-Jumbulati 'Abd al-Futûh. Perbandingan Pendidikan Islam, terj. M. Arifin, Jakarta: Rineka Cipta, 1994.

Amiruddin, M. Hasbi. Dayah 2050: Menatap Masa Depan Dayah di Era Transformasi Ilmu dan Gerakan Keagamaan. Yogyakarta: Hexagon, 2013.

Amiruddin, M. Hasbi. Menatap Masa Depan Dayah di Aceh. Banda Aceh: Yayasan PeNA, 2008.

Amiruddin, M. Hasbi. Ulama Dayah, Pengawal Agama Masyarakat Aceh. Lhokseumawe: Nadiya Foundation, 2003.

Asih, Menanti, et al. Membangun Budaya Akademik di Universitas Negeri Medan. Medan: Unimed, 2012.

Daradjat, Zakiah, et al. Ilmu Pendidikan Islam. Jakarta: Bumi Aksara, 2008.

Daulay, Haidar Putra. Historitas dan Eksistensi Dayah Sekolah dan Madrasah. Yogyakarta: Tiara Wacana Yogya, 2001. 
Departemen Pendidikan dan Kebudayaan. Kamus Besar Bahasa Indonesia. Jakarta: Balai Pustaka, 1991.

Dhofier, Zamakhsyari. Tradisi Pesantren: Studi tentang Pandangan Hidup Kyai. Jakarta: LP3ES, 1985.

Fernandez, S.O. Citra Manusia Budaya Timur dan Barat. NTT: Nusa Indah, 1990.

Hadi, Abdul. "Konsep Pendidikan al-Fârâbî dan Ibn Sînâ," dalam Jurnal Ilmiah Sintesa, Vol. 9. No. 2, Januari 2010.

Hasjmy, Ali. Sejarah Kebudayaan Islam di Indonesia. Jakarta: Bulan Bintang, 2005.

Hikmat. Manajemen Pendidikan. Bandung: Pustaka Setia, 2009.

Idris, Jamaluddin. Sekolah Efektif dan Guru Efektif. Banda Aceh: Taufiqiyah Sa'adah, 2006.

Indrafchrudi, Soekarto. Bagaimana Mengakrabkan Sekolah dengan Orang Tua Murid dan Masyarakat. Malang: IKIP Malang, 1994.

Karim, M. Rusli. Pendidikan Islam di Indonesia. Yogyakarta: Tiara Wacana Yogya, 1991.

Koentjaraningrat. Pengantar Antropologi. Jakarta: Aksara, 1969.

Koentjaraningrat. Pengantar Ilmu Antropologi. Jakarta: Rineka Cipta, 2002.

Koentjaraningrat. Rintangan-rintangan Mental dalam Pembangunan Ekonomi di Indonesia. Jakarta: Lembaga Riset Kebudayaan Nasional Seni, 1969.

Maarif, Ahmad Syafii, et al. Pendidikan Islam di Indonesia: Antara Cita dan Fakta. Yogyakarta: Wacana Yogya, 1991.

Madjid, Nurcholish. Bilik-Bilik Pesantren: Sebuah Potret Perjalanan. Jakarta: Madina, 1997.

Mastuhu. Dinamika Sistem Pendidikan Pesantren. Jakarta: INIS, 1994.

Muhaimin \& Abdul Mujib. Pemikiran Pendidikan Agama Islam: Kajian Filosofis dan Kerangka Dasar Operasionalisasinya. Bandung: Trigenda Karya, 1993.

Muhaimin. Pemikiran dan Aktualisasi Pengembangan Pendidikan Islam. Jakarta: RajaGrafindo Persada, 2011.

Muhtharom. Reproduksi Ulama di Era Globalisasi. Yogyakarta: Pustaka Pelajar, 2005.

Saleh, Abdurrahman. Penyelenggara Pendidikan Formal di Pondok Pesantren. Jakarta: Dirjen Bimbaga Islam Departemen Agama RI., 2005.

Sulaiman, In'am. Masa Depan Pesantren: Eksistensi Pesantren di Tengah Gelombang Modernisasi. Malang: Madani, 2010.

Wiryokusumo, Usman Mulyadi. Dasar-Dasar Pengembangan Kurikulum. Jakarta: Bina Aksara, 1988.

Yusuf, Tahar. "Model Pendidikan Islam Era Modernisasi: Suatu Kajian Teoritis dan Historis.” Pidato Pengukuhan Guru Besar IPI pada IAIN Imam Bonjol Padang, 1994.

Zuchdi, Darmiyati, et al. Pendidikan Karakter dengan Pendekatan Komprehensif: Terintegrasi dalam Perkuliahan dan Pengembangan Kultur Universitas. Yogyakarta: UNY Press, 2010. 